\title{
Kalimantan Islamic Manuscripts: Codicology Perspective
}

\author{
Titik Pudjiastuti \\ \{titikpuji@yahoo.com\} \\ Univeristas Indonesia
}

\begin{abstract}
Kalimantan is one of the five big islands in NKRI. Since 2012 Kalimantan Island has been divided into five provinces, which are West Kalimantan, Central Kalimantan, East Kalimantan South Kalimantan, and North Kalimantan. Based on the information contained in the documents or historical archives and various chronicles, it can be discovered that in the past in Kalimantan consisted of many kingdoms. It is assumed that every kingdom must have written evidence containing information about its history and culture. According to the field research, founded 280 Islamic manuscripts. In this writing, the Kalimantan Islamic manuscripts are studied with codicology perspective not philology approach. It is meaning that more emphasis is given on the physical manuscripts. Some result of this research, the Islamic Kalimantan were: written between $19^{\text {th }}$ and $20^{\text {th }}$ centuries, the scripts not only Arabic but also Jawi (Arabic Malay), Lontara, Hanacaraka, and Pegon, and the materials of manuscript were used European paper and dluwang (Javanese paper).
\end{abstract}

Keywords: Islamic Manuscripts, Kalimantan, Genre, Codicology,

\section{Introduction}

Kalimantan is one of the five big islands in NKRI (the Unitary State of the Republic of Indonesia). Its geographical position lies in the middle zone or the Central Indonesian region. Not all Kalimantan Island belongs to NKRI, as some part of it belongs to Malaysia, which is the northern part of North Kalimantan.

According to history, the ancient Kalimantan Island consisted of three regions based on its three main kingdoms in the past, which were Borneo, Sukadana (Tanjungpura), and Banjarmasin. However, since 2012 Kalimantan Island under NKRI has been divided into five provinces, which are West Kalimantan whose capital city is Pontianak, Central Kalimantan whose capital city is Palangka Raya, East Kalimantan whose capital city is Samarinda, South Kalimantan whose capital city is Banjarmasin, and North Kalimantan whose capital city is Tanjungselor. Based on the information contained in the documents or historical archives and various chronicles, such as Hikayat Banjar and Kotawaringin [1] Salasilah Kutai [2] and Kerajaan Bima [3] it can be discovered that in the past in Kalimantan consisted of many kingdoms that had their glories in the cultural, social, economic, and political fields. Among these many kingdoms were Kutai Sultanate, Banjarmasin Sultanate, and Pontianak Sultanate. 
It is assumed that every kingdom must have written evidence containing information about its history and culture. Therefore, in every kingdom there is certainly some written evidence containing information about its history and culture. Based on this assumption, research on ancient manuscripts of Kalimantan (hereinafter referred to as "manuscripts") was conducted.

In 2008, a researcher team from the Religious Research and Development Board, in the Field of Literature, Religious Reading, and Organization Management, the Ministry of Religious Affairs of the Republic of Indonesia conducted research and digitalization of religious manuscripts found in East Kalimantan, particularly those found in Paser, Sebakung, and Samarinda areas. The research results have been published in a book entitled Katalog Naskah Keagamaan Maluku Utara, Sulawesi Selatan, Maluku, Sulawesi Barat, Sulawesi Teggara, Papua Barat, Gorontalo [4] From this observation, it was discovered that the number of East Kalimantan manuscripts contained in the catalogue is 47.

In 2009 Achadiati conducted research and recorded the manuscripts of Kalimantan restored at a museum in West Kalimantan by Yayasan Pesisir Sambas, the Board of History and Traditional Value Studies of Pontianak City, Lambung Mangkurat Museum, Syekh Arsyad al-Banjari Museum, Banjarmasin Language Board in South Kalimantan, and Mulawarman Museum in East Kalimantan. The recorded manuscripts have been described and made into a catalogue and published with the title Katalog Naskah Kalimantan [5]. Based on further in-depth examination on the content, it was discovered that the number of the Kalimantan manuscripts recorded in the catalogue is 181. Those manuscripts are divided into 18 types of texts, which are astronomy, languages, literature, prayers, fiqh, hadiths, hikayat (folklores), arithmetic, Islamic theology, horoscope, al-Quran, history, genealogy, letters, poetry, sufism, laws, and so on.

In 2017, I together with a team from the Philology Laboratory of the Faculty of Humanities of Universitas Indonesia, conducted a field research project to record and digitalize the manuscripts as part of the literary heritage of Pontianak people in West Kalimantan. The results of the research show that there were 179 Pontianak manuscripts restored by 11 manuscripts owners. Based on the genre of the texts, those 179 manuscripts are divided into 16 types of texts based on their main theme or content, consisting of languages, agriculture, journals, hikayat (folklore), law, trading law, Islam, talismans, exhortations, medicine, horoscope, rhetoric, literature, history, genealogy, and letters.

In 2018, The Philology Laboratory of the Faculty of Humanities of Universitas Indonesia Team and I conducted a further research project in Central and South Kalimantan. In both provinces, 129 manuscripts managed to be recorded and digitalized. Based on our observation on the texts' contents, it was discovered that there are nine types of texts, which are languages, Islam, charms, medicine, horoscope, literature, history, letters, and others.

When the text types were observed, it was discovered that 41 out of 47 East Kalimantan manuscripts that had been studied by the researcher team from the Religious Research and Development Board of the Ministry of Religious Affairs contain Islamic religious texts, which consist of 6 al-Quran manuscripts, 9 prayer manuscripts, 4 fiqh (theological) manuscripts, 3 talisman manuscripts, 4 barzanji/dzikir manuscripts, 3 tasawuf manuscripts, 7 tarekat manuscripts, 1 sermon manuscript, 2 prophet history manuscripts, 1 shalawat manuscript, and 1 prophet hadith manuscript, while the rest is about grammar, literature, and sexology (Buginese).

Meanwhile, out of 181 manuscripts recorded in the book entitled Katalog Naskah Kalimantan, 66 are Islamic manuscripts. The details are as follows: 19 al-Quran manuscripts, 5 tarekat manuscripts, 5 tauhid manuscripts, 7 tasawuf manuscripts, 20 fiqh manuscripts, 2 falak manuscripts, 1 hadith manuscript, 1 prayer manuscript, and 6 aqidah manuscripts. 
Moreover, the number of West Kalimantan manuscripts is 179,123 of which were discovered to be Islamic manuscripts consisting of 33 al-Quran manuscripts, 13 fiqh manuscripts, 10 tauhid manuscripts, 3 tarekat manuscripts, 2 tasawuf manuscripts, 2 hadith manuscripts, 5 maulid manuscripts, 3 risalah manuscripts, 23 prayer manuscripts, 11 aqidah manuscripts, 8 wirid manuscripts, and 10 shalawat manuscripts.

Meanwhile, the number of Central and South Kalimantan manuscripts is 129, and it was discovered that 50 of them are Islamic manuscripts. Those manuscripts consist of 11 al-Quran manuscripts, 8 prayer manuscripts, 1 wirid manuscript, 3 shalawat manuscripts, 3 tarekat manuscripts, 5 tauhid manuscripts, 5 tasawuf manuscripts, 5 fiqh manuscripts, 1 hadith manuscript, 5 aqidah manuscripts, 2 risalah manuscripts, and 1 maulid manuscript.

\section{Research Method}

To this date, many papers produced from the manuscript studies are philological in nature, meaning that they are based on texts with final results in a form of text editing and the study of the contents. The philological manuscript studies are similar with the codicological manuscript studies, as they rely on physical manuscripts with the purpose of discovering the history of the manuscripts, and these are very rarely conducted.

In this writing, the Kalimantan Islamic manuscripts are studied with codicology perspective, meaning that more emphasis is given on the physical manuscripts. This type of study is necessary to raise the awareness of the academic community that there are other approaches that can be applied to study manuscripts. By means of manuscript studies, it is expected that the history of the Kalimantan Islamic manuscripts can be constructed, which includes the time period when the writing tradition started to be done, the scriptorium responsible for the tradition, the purpose of the manuscript creation, and the writers that produced the manuscripts. However, before these pieces of information can be found, the theoretical background and the codicological methods applied in this paper must be explained first. Codicology is an academic discipline whose role is to support another discipline, i.e. philology. This branch of science was first introduced to the greater public by Alphonse Dain in the book entitled Les Manuscrits, published in 1949. Codicology is a science on manuscripts and not a science on what is written in the manuscripts. This discipline covers a rather broad range of topics which consist of, among others, manuscript history, manuscript collection history, scriptorium, the making of a catalogue, and manuscript trading. As a science which seeks to learn and study the physical aspects of manuscripts, including documents or letters, codicology aims to explore manuscript history.

Codicology has several types of work method which depend on the research objective. In research aiming to make a catalogue of manuscripts, the first step that has to be done is to record the physical elements of the manuscripts, including the cover, title, material, language, alphabet, illumination, page number, line number, writer or copier, internal and external notes related to the manuscripts, and others. After all of the elements are recorded, the next step is to write a manuscript description; furthermore, based on the manuscript description, a manuscript catalogue is produced. The sequence of the descriptions presented in a manuscript catalogue can be determined based on the text genre or the name of the manuscript owner, institution, or collector, depending on the subjective evaluation of the catalogue organizer. For this purpose, a number of relevant works, such as Kodikologi Melayu di Indonesia [6], De Descriptione Codicum[7], Les Manuscrit [8], and Writing Material of the East written[9] can 
be used as references. This paper does not aim to make a manuscript catalogue but only seeks to deliver information about the physical elements of Kalimantan Islamic manuscripts, so that the condition of those manuscripts can be determined and their history constructed.

\section{Results And Discussion}

The physical elements of Kalimantan Islamic manuscripts are discussed below and include the cover, title, material, language, alphabet, illumination, colophon, stamp, and condition of the manuscript. Analysis is presented for each of those elements as follows.

a. The cover

The covers of the Kalimantan Islamic manuscripts quite vary; they have different forms, and some were made from animal skin, thick carton, thin carton, or thin dluwang. However, there are many that do not have any cover because the cover is missing or the manuscript is already severely damaged. Most manuscripts of al-Quran, prayer collection, and Islamic teachings have skin cover, and some are in black, dark red, or brown color with an envelope flap and fore-edge flap. Academic works on manuscript covers from various regions in Indonesia are kept in UBL (Leiden University Library) and Koninklijk Instituut Voor Taal-, Land-, en Volkenkunde (KITLV), and they have been discussed by Plom [10].

b. The title

Most Kalimantan Islamic manuscripts do not have any title. With regard to manuscripts that do not have a title, the editor will provide the title based on the contents of the text.

c. The manuscript material

Based on our observation on the manuscript material, it was discovered that many of the Kalimantan Islamic manuscripts were written on European paper. European paper can be recognized from various kinds of paper stamp called watermark, countermark, chain line, and laid line. Based on the paper stamp, the origin of the paper and the age of the paper can be discovered by referring to a list of paper stamps made by Churchil [11], Heawood[12], or Voorn[13]. Watermark that can be seen on Kalimantan Islamic manuscripts is in the form of pictures including, among others, Lion in Medallion, Concordia resparvae rescent, Propatria, Man in the Moon, Propatria Eiusque Libertate, Strasburg Lily, and Crown Lily. Meanwhile, we also found countermark in the form of alphabetical writing, such as J. Honig and Great Britania. Besides that, there are also many types of European paper that only have chain line and laid line. One work on European paper can be read in an article written by Russel Jones[14]

In addition to European paper, there are quite many Kalimantan Islamic manuscripts whose material was made of dluwang. In Javanese, dluwang means paper which is made of Sepukau (in Latin: Broussonetia papyrifera Vent) bark. The process of making dluwang from bark to paper material can be read in the writing by Edi S. Ekadjati and John H. McGlyn[15] and Titik Pudjiastuti[16]

In Pontianak, there are some manuscripts with lontar material whose contents are about talismans. The lontar manuscript material was made of siwalan leaves. The term lontar is the metathesis of the Javanese phrase ron tal meaning tal leaves (i.e. siwalan leaves). The process of making lontar as the manuscript material can be read in the writing by Titik Pudjiastuti Other material that can be found in the collection of Kalimantan Islamic manuscripts is plain paper and line paper. 


\section{d. The language}

The languages used in Kalimantan Islamic manuscripts quite vary, and they consist of Arabic, Malay, Javanese, and Buginese-Makassarese language.

e. The alphabet

The alphabets used in Kalimantan Islamic manuscripts quite vary, and they consist of Arabic, Jawi (Arabic-Malay), Pegon (Arabic-Javanese), and Lontarak.

f. The illumination

The basic definition of illumination is a picture on a manuscript. According to Behrend[17] illumination is the embellishment or highlighting of objects written or drawn on manuscript pages by applying certain writing techniques, coloring patterns, decorations, or other complementary attributes, such as decorative punctuations, frames, rubrication, and calligraphy.

At first, illumination was connected to gold plating in several manuscript pages to make the manuscript beautiful[18]. However, along with its development, illumination has been understood not only as decoration in the form of pictures or frames on the front part (frontispiece) of a text, but also an integral part of the whole text[19].

In regard to Javanese manuscripts, Sri Ratna Saktimulya[20] states that the text framing an ornamental picture is called wedana, while the illustration or picture helping to clarify the text's contents is called rerenggan. Based on our observation on the illuminations contained in the manuscripts, it seems that most of Kalimantan Islamic manuscripts with illuminations are al-Quran manuscripts. Besides illuminations in the form of wedana, there are also manuscript decorations in the form of illustrations (i.e. pictures supporting the content of the text).

g. Colophon

According to Dain colophon is the last part of a manuscript, while Chambert-Loir [21] defines it as the last paragraph added intentionally by the copier. In a colophon, we usually find pieces of historical information about (a) the work or text copied, consisting of the author(s), place and date of writing, condition, and purpose of the writing and (b) the manuscript itself, consisting of the date of writing, the name of the copier, the place of writing, manuscript details, manuscript owner(s), and the source of the manuscript. Not many Kalimantan Islamic manuscripts have a complete colophon, and several manuscripts only mention the date or time of writing without the year number.

h. Condition of the Manuscript

Judging from their appearance, Kalimantan Islamic manuscripts that are the collection of the Museum and Yayasan Islam Dalam Pagar are quite well preserved, although some are not really in a good condition. However, manuscripts that are possessed by private individuals are mostly not in a good condition: they tend not to have any cover, their sheets are torn, or the ink is damaging the paper so that the alphabets can no longer be read [22].

\section{Conclusion}

From the discussion above, there are several conclusions that can be drawn. First, based on our observation, the number of the Kalimantan manuscripts that have been recorded is 536 . Of this number, 280 or around $53 \%$ are Islamic manuscripts. This shows that Islam had been an 
integral part of life in some communities in Kalimantan at the time the manuscripts were written.

Second, based on the watermark and countermark discovered on the manuscript material, it can be predicted that Kalimantan manuscripts were written between $19^{\text {th }}$ and $20^{\text {th }}$ centuries. This time period is further confirmed by the written information contained in the colophons which mostly mention the year in which the manuscript was produced. Based on this, it can be concluded that the Kalimantan manuscript written tradition flourished throughout that period.

Third, based on the fact that the lontara alphabet was used quite extensively as the medium for writing the Kalimantan manuscript, it can be predicted that during that time, there were many Buginese or Makassarese people in Kalimantan who also took part in the written tradition in Kalimantan.

Fourth, with regard to the use of dluwang as manuscript material, the use of the hancaraka and pegon alphabets, and the use of Javanese language in the production of Kalimantan manuscripts, we can assume that the Kalimantan people maintained a good relationship with the Javanese people in the past. Another possibility is that the Kalimantan people often went to Java Island to buy dluwang to be used as the material for their manuscripts or to buy finished manuscripts already made from dluwang material and written in the pegon alphabets and Javanese language and bring them to Kalimantan. In this way, the manuscripts with dluwang material, Javanese language, and pegon alphabets might become part of the Kalimantan manuscript collection.

Fifth, Katalog Naskah Kalimantan mentions that there are Kalimantan manuscripts which were made from cassava paper and straw paper. This paper wishes to clarify that this is not true: it is improbable that any of the paper sheets was made of cassava because, if the sheets were really made of cassava, they would have been eaten by insects and mice. The same also holds true for straw paper: it is impossible to make paper sheets out of straw because it is not a strong type of material and can only be used as writing books for school children, food wrappers, and sacred paper for the adherents of Confucianism. Hence, the "cassava and straw paper" as mentioned in Katalog Naskah Kalimantan must have referred to dluwang.

Sixth, most Kalimantan manuscripts are not well maintained. This probably happens because the owners or the institutions keeping the manuscripts do not really understand how to maintain their ancestors' heritage properly.

\section{References}

[1] J. J. Ras, Hikayat Banjar dan Kotawaringin. The Hague: Martinus Nijhoff, 1968.

[2] Adham, Salasilah Kutai. Tenggarong, 1980.

[3] Salahuddin and Mariam, Kerajaan Bima. Bima: Museum Samparaja Behrend, 1988.

[4] Tim Peneliti Departemen Agama RI, Katalog Naskah Keagamaan Maluku Utara, Sulawesi Selatan, Maluku, Sulawesi Barat, Sulawesi Teggara, Papua Barat, Gorontalo. Jakarta: Departemen Agama RI, 2017.

[5] D. Kramadibrata and M. Buduroh, Katalog Naskah Kalimantan. Jakarta: Yayasan Naskah Nusantara bekerjasama dengan The Ford Foundation, 2010.

[6] S. W. R. Mulyadi, Kodikologi Melayu di Indonesia. Depok: Fakultas Sastra UI, 1995.

[7] Hermans Jos. M.M and G. Huisman, C., De Descriptione Codicum. Groningen: Vakgroep Mediaevistiek, Rijksuniversiteit Groningen. Gronigen: Vakgroep Mediaevistiek, Rijksuniversiteit Groningen.

[8] A. Dain, Les Manuscrits. Paris: Les Belles Lettres, 1975.

[9] A. Gaur, Writing material of the east. London: The British Library, 1975.

[10] M. Plom, “"Tradisional bookbindings from Indonesia . Materials and Decoration' in BKI 149," 
BKI, vol. 149, pp. 571-592, 1993.

[11] W. A. Churchill, Watermarks in Paper in Holland, England, France, etc. in the XVII and XVIII Centuries and Their Interconnection. Amsterdam: Menno Hertzberger, 1935.

[12] E. Heawood, Watermarks : mainly of the 17th and 18th centuries. Hilversum: Paper Publications Society, 1950.

[13] H. Voorn, De Papiermolens in de Provincie Noord Holland. Haarlem: Papierwerld, 1960.

[14] R. Jones, "European and Asian papers in Malay manuscripts; A provisional assessment," Bijdr. tot taal-, land- en Volkenkd. / J. Humanit. Soc. Sci. Southeast Asia, 1993.

[15] E. S. Ekadjati and J. H. M. Glyn, Daluang: Traditional Paper Production” in Illuminations: The Writing Tradtions of Indonesia. Jakarta, New York and Tokyo: Lontara, Weatherhill, Inc., 1996.

[16] T. Pudjiastuti, “'Kertas Tradisional' dalam Naskah dan Studi Naskah, Sebuah Antologi,” in Seri Kajian Filologi, Bogor: Academia, 2006.

[17] T. . Behrend, "Textual Gateways: The Javanese Manuscripts Tradition" in Illuminations: The Writing Tradtions of Indonesia. Jakarta, New York and Tokyo: Lontara, Weatherhill, Inc., 1996.

[18] R. Folsom, The Calligraphers Dictionary. London: Thames and Hudson, 1990.

[19] Mu'jizah, Iluminasi dalam Surat-Surat Melayu Abad ke -18 dan ke-19. Jakarta: KPG, École française d'Extrême-Orient, Pusat Bahasa- Departemen Pendidikan Nasional- KITLV, 2009.

[20] S. R. Saktimulya, Naskah-Naskah Scriptorium Pakualaman Periode Pakualama II (1830-1858): Kajian Kodikologi, Filologi, dan Hermeutika. Jakarta: : École française d'Extrême-Orient, 2015.

[21] H. Chambert-Loir, "Kolofon Melayu" in Filologi dan Islam Nusantara. Jakarta: Kementrian Agama RI Badan Litbang dan Diklat Puslitbang Lektur Keagamaan., 2010.

[22] K. Saddhono and S. Supeni. "The role of dutch colonialism in the political life of Mataram dynasty: A case study of the manuscript of Babad Tanah Jawi." Asian Soc. Sci. vol. 10 no.15 pp. $1-7,2014$ 